\title{
Catalysis for Global Development. Contributions around the Iberoamerican Federation of Catalysis
}

\author{
Helder Gomes $1,2, *\left(\mathbb{D}\right.$ and Joaquim Faria ${ }^{2}(\mathbb{D})$ \\ 1 Centro de Investigação de Montanha (CIMO), Instituto Politécnico de Bragança, 5300-253 Bragança, Portugal \\ 2 Laboratory of Separation and Reaction Engineering-Laboratory of Catalysis and Materials (LSRE-LCM), \\ Faculdade de Engenharia, Universidade do Porto, 4200-465 Porto, Portugal; jlfaria@fe.up.pt \\ * Correspondence: htgomes@ipb.pt
}

Received: 28 February 2020; Accepted: 11 March 2020; Published: 19 March 2020

Following biennial meetings held since 1968, the Iberoamerican Federation of Catalysis Societies (FISoCat), the Portuguese Chemical Society (SPQ) and the University of Coimbra jointly organized the XXVI Iberoamerican Congress on Catalysis (CICat 2018), which took place in the historic city of Coimbra, Portugal, between the 9th and 14th of September 2018. CICat 2018 was of particular importance in the history of these events, as it marked the 50th anniversary since the beginning of this series of meetings-by far the most important in the field of catalysis in the Iberoamerican region. Associated with the commemoration of this event, this Special Issue, Catalysis for Global Development: Contributions around the Iberoamerican Federation of Catalysis, emerged to feature selected works presented at CICat 2018. Other possible additional contributions promoting linkages among catalytic science, technology, education, and culture plans and processes involved in cooperation programs and projects among the Iberoamerican Member States, as well as states and institutions of other regions, were also envisaged.

The topics of the conference covered various aspects of catalysis in all its diversity (environmental catalysis, industrial catalysis, oil refining, natural gas conversion and petrochemistry, catalyst design, preparation and characterization, sustainable processes and clean energies, fine chemistry, and other topics on biocatalysis, homogeneous and heterogeneous catalysis), as well other related areas. The diversity of the topics covered was evidenced by the 442 delegates from 20 countries, mostly Iberoamerican countries, attending the conference, and by the presentation of 510 works, together with five plenary lessons-one lesson alluding to the history of CICat to celebrate their 50 years-eight keynotes, and six awards given during the event.

Its extensive scope and interdisciplinarity affirm catalysis to be an essential part of the process and the chemical industry. Research in catalysis supports several strategic industrial sectors in Iberoamerica development through products and processes from energy to the manufacture of materials, and has implications for the development of digital applications and devices. Catalysis plays a crucial role in environmental protection, whether by recycling waste or by reducing gas emissions that contribute to increasing global warming - thereby opening new routes for eco-friendly processes and products that are sustainable and ecologically correct. It is on these topics and directly-related subjects that sixteen selected contributions from the Iberoamerican Federation of Catalysis are gathered in this Special Issue [1-16].

We believe that the contributions published will serve as a source of inspiration and guidance to all those involved in the exciting field of catalysis, particularly for the young researchers and students taking their first steps into research on catalysis. We would like to thank the authors for their enthusiasm since the call for papers was opened, showing from the very earliest stages of the production of the Special Issue their motivation to contribute to this collection. Finally, we acknowledge the unmeasurable help of the assistant editors and reviewers involved, which allowed speeding up the production process and promoting the quality of the manuscripts presented in this Special Issue, making it, so far, the most successful conference issue in Catalysts. 
Conflicts of Interest: The authors declare no conflict of interest

\section{References}

1. Carriel Schmitt, C.; Gagliardi Reolon, M.; Zimmermann, M.; Raffelt, K.; Grunwaldt, J.; Dahmen, N. Synthesis and Regeneration of Nickel-Based Catalysts for Hydrodeoxygenation of Beech Wood Fast Pyrolysis Bio-Oil. Catalysts 2018, 8, 449. [CrossRef]

2. Tomé, V.; Calvete, M.; Vinagreiro, C.; Aroso, R.; Pereira, M. A New Tool in the Quest for Biocompatible Phthalocyanines: Palladium Catalyzed Aminocarbonylation for Amide Substituted Phthalonitriles and Illustrative Phthalocyanines Thereof. Catalysts 2018, 8, 480. [CrossRef]

3. Hurtado, B.; Posadillo, A.; Luna, D.; Bautista, F.; Hidalgo, J.; Luna, C.; Calero, J.; Romero, A.; Estevez, R. Synthesis, Performance and Emission Quality Assessment of Ecodiesel from Castor Oil in Diesel/Biofuel/Alcohol Triple Blends in a Diesel Engine. Catalysts 2019, 9, 40. [CrossRef]

4. Parejas, A.; Cosano, D.; Hidalgo-Carrillo, J.; Ruiz, J.; Marinas, A.; Jiménez-Sanchidrián, C.; Urbano, F. Aldol Condensation of Furfural with Acetone Over Mg/Al Mixed Oxides. Influence of Water and Synthesis Method. Catalysts 2019, 9, 203. [CrossRef]

5. Sánchez-Bayo, A.; Morales, V.; Rodríguez, R.; Vicente, G.; Bautista, L. Biodiesel Production (FAEEs) by Heterogeneous Combi-Lipase Biocatalysts Using Wet Extracted Lipids from Microalgae. Catalysts 2019, 9, 296. [CrossRef]

6. Montaña, M.; Leguizamón Aparicio, M.; Ocsachoque, M.; Navas, M.; de CL Barros, I.; Rodriguez-Castellón, E.; Casella, M.; Lick, I. Zirconia-Supported Silver Nanoparticles for the Catalytic Combustion of Pollutants Originating from Mobile Sources. Catalysts 2019, 9, 297. [CrossRef]

7. Silva, L.; Neves, V.; Ramos, V.; Silva, R.; Campos, J.; Silva, A.; Malta, L.; Senra, J. Layered Double Hydroxides as Bifunctional Catalysts for the Aryl Borylation under Ligand-Free Conditions. Catalysts 2019, 9, 302. [CrossRef]

8. Fidelis, M.; Abreu, E.; Dos Santos, O.; Chaves, E.; Brackmann, R.; Dias, D.; Lenzi, G. Experimental Design and Optimization of Triclosan and 2.8-Diclorodibenzeno-p-dioxina Degradation by the Fe/Nb2O5/UV System. Catalysts 2019, 9, 343. [CrossRef]

9. Escobar, J.; Barrera, M.; Valente, J.; Solís-Casados, D.; Santes, V.; Terrazas, J.; Fouconnier, B. Dibenzothiophene Hydrodesulfurization over P-CoMo on Sol-Gel Alumina Modified by La Addition. Effect of Rare-Earth Content. Catalysts 2019, 9, 359. [CrossRef]

10. Aiube, C.; Oliveira, K.; Macedo, J. Effect of Cerium Precursor in the Synthesis of Ce-MCM-41 and in the Efficiency for Liquid-Phase Oxidation of Benzyl Alcohol. Catalysts 2019, 9, 377. [CrossRef]

11. Dominguez, C.; Romero, A.; Santos, A. Improved Etherification of Glycerol with Tert-Butyl Alcohol by the Addition of Dibutyl Ether as Solvent. Catalysts 2019, 9, 378. [CrossRef]

12. Gutiérrez-Ortega, N.; Ramos-Ramírez, E.; Serafín-Muñoz, A.; Zamorategui-Molina, A.; Monjaraz-Vallejo, J. Use of $\mathrm{Co} / \mathrm{Fe}-M i x e d$ Oxides as Heterogeneous Catalysts in Obtaining Biodiesel. Catalysts 2019, 9, 403. [CrossRef]

13. Freitas, C.; Pereira, M.; Souza, D.; Fonseca, N.; Sales, E.; Frety, R.; Felix, C.; Azevedo, A.; Brandao, S. Thermal and Catalytic Pyrolysis of Dodecanoic Acid on SAPO-5 and Al-MCM-41 Catalysts. Catalysts 2019, 9, 418. [CrossRef]

14. Ramos-Ramírez, E.; Tzompantzi-Morales, F.; Gutiérrez-Ortega, N.; Mojica-Calvillo, H.; Castillo-Rodríguez, J. Photocatalytic Degradation of 2,4,6-Trichlorophenol by MgO-MgFe2O4 Derived from Layered Double Hydroxide Structures. Catalysts 2019, 9, 454. [CrossRef]

15. Tavizón-Pozos, J.; Santolalla-Vargas, C.; Valdés-Martínez, O.; de los Reyes Heredia, J. Effect of Metal Loading in Unpromoted and Promoted CoMo/Al2O3-TiO2 Catalysts for the Hydrodeoxygenation of Phenol. Catalysts 2019, 9, 550. [CrossRef]

16. V. Sales, R.; Moura, H.; Câmara, A.; Rodríguez-Castellón, E.; Silva, J.; Pergher, S.; Campos, L.; Urbina, M.; Bicudo, T.; de Carvalho, L. Assessment of Ag Nanoparticles Interaction over Low-Cost Mesoporous Silica in Deep Desulfurization of Diesel. Catalysts 2019, 9, 651. [CrossRef]

(C) 2020 by the authors. Licensee MDPI, Basel, Switzerland. This article is an open access article distributed under the terms and conditions of the Creative Commons Attribution (CC BY) license (http://creativecommons.org/licenses/by/4.0/). 